\title{
WHAT IS A REALIST THEORY OF LAW?
}

BRIAN LEITER ${ }^{1}$

This essay offers a programmatic statement for a realist theory of law. Although I have been influenced by (and written about) the work of earlier American, Scandinavian, Italian and other legal realists, this is not an essay about what others have thought. This is an essay about what I take realism about law to mean and what its theoretical commitments are; I shall use other realists to sometimes illustrate the distinctive positions of a realist theory of law, but will make clear where I depart from them.

A realist theory of law involves both a "realist" and a "naturalistic" perspective on law. Let me explain how I understand these perspectives.

"Realism" describes a theoretical outlook that is no longer fashionable in the universities, and also one that has nothing to do with the metaphysical doctrine picked out by the same word. Realists in the latter sense are concerned only about the mind-independent status of some class of entities (for example, values). By contrast, "realism" in the sense at issue here takes no stand on metaphysical questions, that is, the "scholastic" question, as Marx called it, about the "reality or non-reality of thinking."

Realism, in the sense at issue for jurisprudence, reflects a quite different intellectual tradition, usually associated with Thucydides, Machiavelli, and Nietzsche, among others (see, e.g., Leiter 2012). There are two key components of realism in this sense. First, realists aim to describe how things really are without romantic or moralizing illusions. We want to know what law and legal institutions are like in reality, not what we might wish them to be. Realists also do not suppose that the way things are will make "moral sense" or turn out to be morally defensible: it can (and often does) turn out that law and its operations are morally objectionable or worse. Realists can be animated by normative hopes, certainly, but they do not build them in to the account of their subject-matter (contrast, for example, Ronald Dworkin's jurisprudence which builds a moral obligation to obey

\footnotetext{
${ }^{1}$ Karl N. Llewellyn Professor of Jurisprudence and Director of the Center for Law, Philosophy \& Human Values, University of Chicago. These thoughts crystallized in the course of a series of seminars on realist jurisprudence I presented at the École des Haute Études en Sciences Sociales in Paris in June 2019. I am grateful to Prof. Otto Pfersman for inviting me and for his contributions to the seminars, as well as those of the students. I was also helped by discussion with students in my fall 2019 graduate seminar on current issues in general jurisprudence at the University of Chicago. Finally, I am grateful to Joshua Fox, a PhD student at the University of Chicago, for outstanding research assistance. Email: bleiter@uchicago.edu.
} 
the law into his account of the nature of law). In the first instance, we need to understand what is really going on: for example, what are people's real motivations, what are they actually doing (independent of what they say they are doing). Thucydides and Machiavelli are the lodestars of the realist tradition in political thought: do not pay attention to the self-serving pontifications of the leaders of Greek or Italian city-states, they teach us; understand that in reality they are all bent on power, glory and survival. Thucydides sets these facts before the reader, and lets the reader draw the conclusion: unbridled lust for power and glory led to the ruin of Athens. Machiavelli addresses himself to those who rule now, and tells them what they must do to hold on to their power. Realists like Thucydides and Machiavelli tell us how politics really works, in ancient Greece or Renaissance Italy; they withhold moral judgment even if, as with Thucydides, there are morals to be drawn from the story told.

Because realism means understanding reality, realists are necessarily "naturalists" in the following precise sense: in describing and explaining what is really going on they rely only on those mechanisms and entities that are explanatorily fruitful in the successful empirical sciences (those sciences being our only reliable guide to what is real). Naturalism is the second crucial commitment of realist jurisprudence. Of the historical legal realists, the Scandinavians were most explicit about commitment to naturalism, while the Italians and the Americans, in different ways, presuppose a naturalistic worldview (even though the Americans were philosophically unsophisticated). Insofar as only what is naturalistically explicable can be real, naturalism must be central to the realist worldview.

It is important to understand what naturalism does and does not mean in this context. Quine, the most important philosophical naturalist of the $20^{\text {th }}$-century, was, ironically, often a very bad Quinean in many respects. The crucial commitment of naturalism, as even Quine professed, is a posteriori: whatever works in the successful sciences is admissible into a naturalist ontology. Yet Quine remained committed ${ }^{2}$ to two failed scientific research programs: physicalism (the idea that everything real must be reducible to physics) and behaviorism in psychology. As another post-Quinean naturalist philosopher, Jerry Fodor (1975, p. 09-26), pointed out in the 1970s, reduction to physics has not marked the last halfcentury of scientific research; instead, there has been a proliferation of special sciences-biological and cognitive sciences most notably-that proceed without even the pretense of being reducible to physics. As another important postQuinean philosopher, Tyler Burge, has observed:

\footnotetext{
${ }^{2}$ In one of his late works, Pursuit of Truth, Quine (1990, p. 70-73) professed commitment to Davidsonian anomalous monism, although for reasons that seem hard to square with his other commitments.
} 
Promoters of 'naturalizing' [i.e., physicalist reductionist] projects are often driven, I think, by misconceptions of science. These misconceptions breed misconceptions of mind. The notion of representation -- of reference or attribution that can be correct or incorrect and that helps type-individuate kinds of psychological states -- is entrenched not only in common-sense explanation but in scientific explanation in psychology. There is nothing unnatural or supernatural about such explanation. Some of the relevant psychology is well-supported, mathematically rigorous, mature science. There is no basis, even a prima facie one, to the worry that psychological notions are invitations to mystery or miracle. Even if there were such basis, the role that these notions play in powerful empirical science would undermine it... I know of no good ground for thinking that... [psychologists'] explanatory claims must be twisted into the mold of biological or informationtheoretic explanation, or any other explanation in the natural sciences, in order to be explanatorily successful. (BURGE, 2010, p. 296-297)

For naturalists, explanatory and predictive fruitfulness is the mark of the real and the knowable, not some a priori and empirically unmotivated assumption that everything must be reducible to physics. Quine himself was "officially" a resolutely methodological naturalist in this sense-even allowing that we would have to jettison "empiricism" (the view that all knowledge derives from sensory experience) if telepathy turned out to work (QUINE, 1990, -. 20-21) - yet in practice he remained wedded to the failed science of the middle of the last century. That also explains his behaviorism in psychology, long after the collapse of that research program, which began with Noam Chomsky's (1959) famous critique of B.F. Skinner, and was brought to a conclusion by the flourishing of the cognitive sciences that Fodor emphasized and to which he contributed.

In short, naturalism is not committed to physicalism, to the view that only physical events and properties are real. Naturalists take successful empirical sciences as a constraint on their ontology, and we now know that unreduced psychological or mental facts are central to the scientific understanding of human phenomena, contra behaviorism. But it is an equally important upshot of naturalism, as I understand it, that it rules out appeal to all evaluative or normative facts, which play no role in any successful explanatory paradigms in any discipline (LEITER, 2007; 2019, Chapters 1, 2 and 4). Anti-realism about morals in particularthere are no attitude- or mind-independent facts about what is morally right and wrong - is central to naturalism: psychological attitudes towards value (e.g., beliefs or affective responses) are often crucial to explaining human behavior, but we do not need to posit the existence of any mind-independent (objective) facts about moral values. This kind of anti-realism about morals is currently 
controversial among bourgeois philosophers in Anglophone universities, who spend too much time talking to moralizing members of their class and thus suffer from "group polarization" as the social psychologists call it, ${ }^{3}$ but it does have the weight of intellectual history on its side: since Nietzsche, most of modernity has rejected both God and an objectively true morality. The absence of objective facts about moral value is fatal to the views of Dworkin and to the Catholic natural lawyers, among others, but I shall not dwell on that here. They are not part of modernity, and it would surely be best if we could pass over them in silence.

In the preceding sense, legal realism is "realism" and "naturalism" about the social phenomenon known as "law." What do legal realists, so understood, reveal to us about law?

To start, realists about law acknowledge that in any functioning legal system, law operates primarily outside the courts. This was a central contention of H.L.A. Hart's jurisprudence: legally valid norms guide how ordinary people buy homes, make wills, enter contracts, avoid taxes, and structure many other aspects of their lives. Adjudication is a fringe phenomenon in a functioning legal system: most individuals consult lawyers in order to accomplish certain goals, not to end up in court. Jurisprudential theories-once again, Dworkin's most infamously--that organize their claims about the nature of law around what goes on in court are deeply unrealistic. ${ }^{4}$

Yet law outside the courts appears in two guises: what the "law books" say, and what legal and other actors actually do. "Law in the books" and "law in action" is how realists often mark the contrast, and the difference is important: norms for behavior can be legally valid, as Hart showed, but ignored in practice. The posted speed limits on the roads are the most familiar example in many jurisdictions: it is clearly illegal to drive beyond a certain speed limit, and yet it is common for drivers to recognize that no one will actually be sanctioned unless they greatly exceed that limit. In any legal system that has actually existed, there is always a gap between the legally valid rules and the rules that are actually enforced: call this realism about enforcement.

The gap is not just between enforcing the rule "in the books" and enforcing a different norm (as in the speed-limit case), but also between how the rules "in action" are enforced against different parties: here facts about economic class, political power, racial or ethnic identity, and other demographic and social characteristics figure in how the same legally enforced rules play out (this is perhaps most notorious in the arena of how police interact with citizens, but it extends well beyond that arena). A realist theory must also capture this second kind of gap-call it realism about enforcement practices--between the "law in the

3See, e.g., Myers(1975); Lord et al.(1979); Zuber et al. (1992); Sunstein (2002).

${ }^{4}$ Most self-identified realists, including the Americans and the Italians, focus primarily on adjudication, but insofar as they do not generally equate what goes on in courts with a theory of the nature of law, they do not make Dworkin's mistake. 
books" and the "law in action." Realism about enforcement calls attention to the way in which valid legal norms are and are not applied in real life; realism about enforcement practices accepts that legally valid norms are applied in real life, but notes how that application really works.

When we do get to those matters that arise in the courts, legal realists emphasize the inevitable indeterminacy of what we call "legal reasoning," at least in some range of cases (what range of cases will vary by jurisdiction, for reasons that will become apparent). Legal reasoning is supposed to be the "method" by which courts arrive at a judgment based on the facts of the case and the relevant valid law. In reality, in every known jurisdiction, "legal reasoning" may circumscribe the outcome a court can legitimately reach, but it often affords the court latitude about the particular choice of outcome. More precisely, the most plausible version of the indeterminacy thesis about law ${ }^{5}$ is that the class of legal reasons - that is, the reasons that may properly justify a judicial decision-underdetermines the decision a judge must reach; legal reasons limits the possible outcomes to the case, but the judge has available equally legitimate legal arguments for more than one decision even within the circumscribed field of possible decisions. The task of a realist theory of adjudication is both to explain why legal reasoning is indeterminate and identify what influences judges to choose the particular decision they do, within the realm of those that are legally available.

There are various possible grounds of legal indeterminacy: H.L.A. Hart emphasized the "open texture" of natural languages, ${ }^{6}$ while the American and Italian Realists have emphasized the interpretive latitude judges enjoy in how they construe statutory provisions and precedents. ${ }^{7}$ The idea that judges have interpretive latitude is a claim about the legitimate interpretive moves a judge can make when confronted with legal sources, whether legislative or constitutional or judicial. The notion of "legitimacy" at issue here is a thoroughly naturalized one, to be understood in terms of psycho-social facts about legal actors: differing interpretations are "legitimate" insofar as they are accepted in fact by other legal actors, especially other judges, as acceptable interpretations. This is often called a "sociological" conception of legitimacy-social acceptance by others is the mark of "legitimacy"--in contrast to the "philosophical" conception which asks whether the interpretations are really justified by reference to some normative standard. That realists rely on a sociological conception of legitimacy means, of course, that the extent of indeterminacy will vary depending on the facts about the attitudes and practices of officials in different legal jurisdictions. This is as it should be: the scope of the indeterminacy of legal reasoning will vary by jurisdiction, even if every jurisdiction exhibits indeterminacy to some degree. That the conception is sociological also explains why, for example, the American Realists can claim that

${ }^{5}$ Leiter, 2007, pp. 9-12.

${ }^{6}$ Hart, 2012, pp. 124-136.

7See, e.g., Leiter, Naturalizing Jurisprudence, 2007, pp. 73-78; Guastini, 2011. 
indeterminacy is an issue primarily at the various stages of appellate review: this is an empirical claim about the interpretive latitude officials have in those kinds of cases, and is compatible, of course, with legal reasoning being determinate and judicial outcomes being predictable elsewhere in the legal system. ${ }^{8}$

A realist theory of law is necessarily a positivist theory, and a positivist theory is necessarily a realist one. ${ }^{9}$ This is not true, to be sure, of all theories that have claimed to be "positivist" theories, but it is true of the most important one, H.L.A. Hart's, despite his confusions about the American and Scandinavian Realists that I have written about previously (LEITER, 2007, p. 17-18). But Hart is a realist insofar as he recognizes that law operates mostly outside the courts; that inside the courts, some decisions are legally indeterminate; that the nature of law is naturalistically explicable in terms of psycho-social facts about human behaviors and attitudes, particularly those of officials; and that law is not necessarily a good thing, that it has costs, and that it is always an open question whether law generates moral obligations of compliance. Hart's mistake regarding legal reaslim was in taking both the Americans and the Scandinavians to be answering his questions, rather than their own. In both cases, he wrongly understood them to be proffering an analysis of the concept of law, understood as that concept implicit in ordinary language that captured features of law intelligible to an ordinary person familiar with a modern municipal legal system. The American Realists had neither interest in, nor even an understanding of, a project of conceptual analysis, ${ }^{10}$ and in fact presupposed in their arguments for the indeterminacy of legal reasoning a positivist conception of legal validity (LEITER, 2007, p. 59-80). The Scandinavian Realist, Alf Ross - the only one Hart really engaged with - was also quite clear that his project was not one of ordinary-language conceptual analysis, but rather an effort to explain how central legal concepts like "obligation," "duty" and "right" could be located within a fairly austere naturalistic worldview (LEITER, 2020); Ross explicitly acknowledged that this analysis could not do justice to the concept of law deployed by an insider to the legal system. ${ }^{11}$ Hart's misguided, albeit influential, dispute with legal realism has obscured the essential connection between positivist and realist views about law.

The connection is particularly clear in the case of the realist indeterminacy thesis. Any thesis to the effect that legal reasons fail to justify a unique decision in some range of cases presupposes that we know the difference between "legal" and "non-legal" reasons, including "legal" and "non-legal" norms. Positivists and antipositivists will draw the line at different places, and how they draw the line bears on the indeterminacy thesis. If a realist says the judge's decision reflected his moral judgment about the merits of the case, and if the moral considerations the judge

${ }^{8}$ I am grateful to Leslie Green who has pressed me on this issue.

9See Leiter (2020); and Leiter (2007, p. 59-80).

${ }^{10}$ One exception was Felix Cohen, nowhere cited by Hart.

${ }^{11}$ See, Holtermann (2014, p. 165-186). 
relied on would, in fact, only justify one decision (the one the judge reached), that only shows legal reasoning to be indeterminate if, in fact, those moral considerations were not "part of the law" or "legally binding." Hard positivism about law and legal validity ${ }^{12}$ can easily explain this: the moral norms are not accepted as criteria of legal validity from an "internal point of view" - that is, they are neither invoked as justifying a decision, nor are deviations from them criticized by reference to those norms--and so are not part of the rule of recognition. ${ }^{13}$ That positivism is necessary for the realist arguments for indeterminacy to work does not show, of course, that positivism is correct. Positivism is vindicated, however, on naturalistic and explanatory grounds, precisely the same considerations that commend realism: that is, a positivist theory of law figures in the most explanatorily fruitful explanations of legal phenomena, such as judicial decisions. ${ }^{14}$

I mentioned already that a realist theory of law, because it is also a naturalistic theory, eschews reference to objective moral values. Here again Hart (2012, p. 116117 ) is a model realist about law: it is not simply that the existence of law in some society is, on his view, a complicated empirical, not moral, fact (a psycho-social fact about the practices of officials in deciding questions of legal validity, and about the obedience of citizens to legally valid norms), it is that he correctly glosses moral and normative concepts, like "obligation," entirely in behavioral terms, that is, what people are disposed to say and do, rather than in terms of any cognitive (i.e., referential) content those terms might have. So, for example, Hart says that, "Rules are conceived and spoken of as imposing obligations when the general demand for conformity is insistent and the social pressure brought to bear upon those who deviate or threaten to deviate is great...[T]he insistence on importance or seriousness of social pressure behind the rules is the primary factor determining whether they are thought of as giving rise to obligations" (HART, 2012, p. 86-87). This is Hart's reasonable attempt at naturalizing normative talk in terms of things that do exist, namely, the observable behavior (including verbal behavior) of people. Alf Ross pursued a related but different strategy, namely, one of translation of normative talk into talk about predictions of behavior in order to preserve the apparently cognitive content of legal claims. But both theorists share the same naturalistic impulse: to purge their theory of law of reference to normative facts. ${ }^{15}$

\footnotetext{
${ }^{12}$ By "hard positivism" I mean the view that the criteria of legal validity cannot include moral criteria.

${ }^{13}$ Even versions of "soft" positivism are compatible with this conclusion, given that realists most often point to non-legal norms influencing decision that are not norms judges do or would acknowledge as decisive.

${ }^{14}$ See again Leiter (2020); and also Leiter (2009); and Leiter (2007, p. 121-136).

${ }^{15}$ Of the many dubious claims in Scott Shapiro's book Legality (2011), the most startling is related to the issue noted in the text. Shapiro claims that Hart believes that "rules are nothing but social practices" (p. 95) but objects that, "Social rules cannot be reduced to social practices because rules and practices belong to different metaphysical categories. Rules are abstract objects....Practices, on the other hand, are concrete events. They take place within the natural world and causally interact
} 
One must acknowledge that some later positivists in the Anglophone tradition have abandoned the realism and naturalism of Hart's approach; Joseph Raz is the most striking case. Raz is a moral realist in the metaphysical sense: he takes there to be objective moral values, ${ }^{16}$ although his reasons for thinking this are obscure. Dogmatic confidence in the objectivity of value became a feature of Oxford philosophy starting in the 1970s, finding its clearest theoretical articulation decades later in the work of Derek Parfit, as well as other defenders of explicitly nonnaturalist value realism or "realism about reasons." 17 At the same time, Raz remains committed to the positivist thesis that there can be no evaluative or content-based criteria of legal validity. Where Raz's moral realism (in the metaphysical sense) makes itself apparent is in his view that law necessarily claims authority, even if it ultimately lacks a justification for that claim.

On Raz's view, law can only claim authority if it is possible to identify the content of a legal directive without reference to the underlying ("dependent") reasons for that directive. This is a "prerequisite" for claiming authority because what distinguishes a (practical) authority in the first place is that its directives preempt consideration of the underlying reasons (including, e.g., moral reasons) for what we ought to do, and in so doing actually makes it more likely that we will do what we really ought to do. ${ }^{18}$ For a realist, the problem with Raz's argument is that it presupposes a highly moralized and unrealistic conception of what it is for law to claim "authority." Raz understands authority in terms of what he calls "the Service Conception," in which a claim to authority is a claim to provide a subject of authority better "reasons" for acting in accordance with what Raz calls "right reason" than the subject would arrive at without the intermediation of the

with other physical events" (p. 103). Shapiro deems this a "category mistake" on Hart's part, and uses that alleged mistake to motivate the baroque apparatus of his alternative theory. John Gardner and Timothy Macklem (2011), in their devastating critique of the book (https://ndpr.nd.edu/news/legality/), note one possible reply: Hart does not "identify the practice exactly with the rule. He identifies the content of the practice, or part of it, with the content of the rule," so no category mistake there. But Kevin Toh has suggested to me what I think is a stronger response: Hart is only offering a reductive, behavioral analysis of what it is to "accept a rule from an internal point of view"; the unit of analysis is "acceptance of a rule" not "rule." Indeed, the introduction of social rules in The Concept of Law begins with the question, "What is the acceptance of a rule?" (Hart, 2012, p. 55), the answer being the behavior of those who accept the rule, i.e, "criticism (including self-criticism), demands for conformity, and in acknowledgments that such criticism and demands are justified, all of which find their characteristic expressions in the normative terminology of 'ought', 'must', and 'should', 'right' and 'wrong'" (p. 57).

${ }^{16}$ See, e.g., $\operatorname{Raz}(2001)$.

${ }^{17}$ Scanlon (2014) is the strongest representative of the genre in my view; for doubts even about this version, see Leiter (2019, Chapter 4).

${ }^{18}$ Raz offers this argument to show that no legal positivist can allow that there could be contentbased criteria of legal validity; I mostly agree with his conclusion, but not at all for Raz's reasons. See again, Leiter (2020). 
authority. ${ }^{19}$ (We can gloss, for purposes here, "right reason" as what one really ought to do.) This view obviously presupposes Raz's moral realism (and realism about reasons quite generally), one that is incredible from a legal realist, i.e., naturalist, point of view. A legal realist can also rightly wonder: why think that when law claims authority it is claiming to help its subjects do what they really ought to do? Even a cursory glance at the history of the world suggests this is implausible: of course law claims authority in the sense of claiming the right to tell those subject to its jurisdiction what they must do, but the idea that this claim to authority is a claim to Raz's Service Conception looks like a moralizing illusion. Legal systems may often claim that they are requiring people to do what is morally right, or God's will, or in the public interest, or the will of the Führer and so on, and thus claim authority to direct their subjects' behavior, but they do not do so on the basis that they are thereby performing a "service" for their subjects in helping them conform with the demands of "right reason."

Raz, of course, explicitly repudiates Hart's realist approach to jurisprudence. Against Hart's realist aim of a "descriptive jurisprudence," Raz asserts "there is an interdependence between conceptual and normative argument" such that the account "does not necessarily conform to everyone's notion of authority in every detail. It does claim to be an explanatory account in singling out important features of people's conception of authority" (RAZ, 1986, p. 63;65). No theorist thinks their descriptive account conforms "to everyone's notion...in every detail," so this is just a strawman. But where is the evidence that Raz's account even captures some "important features of people's [which people?] conception of authority"? There is none. Raz has simply smuggled in a moralized conception of authority ${ }^{20}$ as providing a service for its subjects - without even the pretense that it satisfies even lax evidential demands of a "descriptive sociology" as Hart, the realist, proposed.

There are some important normative upshots of realism about law. First, given realism about both enforcement and enforcement practices, it is never sufficient to evaluate a legal system to know what the valid legal norms are; one must know both which valid norms are actually enforced and one must know how and against whom they are enforced. Valid legal norms that are just can turn out to be unjust along either dimension; and unjust legal norms can turn out to be just along either dimension. The positivist account of legal validity, which is the only serious account we have, leaves these evaluative questions open (as it should, since it is only an account of validity), and no competing account of legal validity settles them. Those that purport to do so-like Dworkin's and those of some lesser antipositivists - serve only as ideological obfuscations.

Second, given realism about adjudication, we need to rethink the role of judges, especially appellate judges, in a legal system. Since indeterminacy is an inescapable

\footnotetext{
19See Raz (1985).

${ }^{20}$ Moralized in the sense that its main aim is to explain why deference to authority by rational subjects can be justified.
} 
feature of a legal system, judges must be appointed with that fact in mind. Judges are never merely appliers of the law, they must always make new law, if only interstitially, although sometimes they do more than that. ${ }^{21}$ The quality of their moral and political judgment thus matters as much as their distinctively legal competence. The lie that judges are simply the instruments of the law-makers is an ideological illusion that all legal realists oppose, as it deceives the public about the essential role of courts in a polity. Political elites are rarely fooled on this core, of course, which is why they typically care a great deal about the composition of the judiciary. Since, however, there is no known political or economic system in which the preferences of elites are conducive to the well-being of the vast majority, legal realism here has an important role to play in promoting public, and perhaps even democratic, accountability.

\section{REFERÊNCIAS}

BURGE, T. Origins of Objectivity. Oxford: Oxford University Press, 2010.

CHOMSKY, N. Review of Skinner's. Verbal Behavior. Language, v. 35, 1959, p. 26-58.

FODOR, J. The Language of Thought. New York: Thomas Y. Crowell Co, 1975.

GARDNER, J.; MACKLEM, T. Review of Legality by Scott Shapiro. Notre Dame Philosophical Reviews, 2011. See https://ndpr.nd.edu/news/legality/.

GUASTINI, R. Rule-Scepticism Restated. In: GREEN, L.; LEITER, B. (eds.). Oxford Studies in the Philosophy of Law, v. 1. Oxford: Oxford University Press, 2011.

Hart, H.L.A. (2012). The Concept of Law. $3^{\text {rd }}$ Edition, Oxford: Oxford University Press.

HOLTERMANN, J. Naturalizing Alf Ross's Legal Positivism: A Philosophical Reconstruction. Revus, v. 24, 2014, p. 165-186.

LEITER, B. Naturalizing Jurisprudence. Oxford: Oxford University Press, 2007.

LEITER, B. Explaining Theoretical Disagreement. University of Chicago Law Review, v. 76, 2009, p. 1215-1250.

${ }^{21}$ See, e.g., Leiter (2015); Spanish translation as Leiter (2016). 
LEITER, B. Praise of Realism (and Against Nonsense Jurisprudence). Georgetown Law Journal, v. 100, 2012, p. 865-893.

LEITER, B. Constitutional Law, Moral Judgment, and the Supreme Court as Super-Legislature. Hastings Law Journal, v. 66, 2015, p. 1601-1616.

LEITER, B. Derecho Constitucional, Juicio Moral y la Supreme Corte como SúperLegislatura. In: VERÁSTEGUI, A. Martínez (ed.). La Constitución como objeto de interpretación. Ciudad de México: Supreme Corte de Justicia de la Nación, 2016.

LEITER, B. Moral Psychology with Nietzsche. Oxford: Oxford University Press, 2019.

LEITER, B. Legal Positivism as a Realist Theory of Law. In: MINDUS, P.; SPAAK, T. (eds.). The Cambridge Companion to Legal Positvism. Cambridge: Cambridge University Press, 2020.

LORD, C. G.; ROSS, L.; LEEPER, M.R. Biased assimilation and attitude polarization: The effects of prior theories on subsequently considered evidence. Journal of Personality and Social Psychology, v. 37, n. 11, 1979, p. 2098-2109.

MYERS, D. Discussion-Induced Attitude Polarization. Human Relations, v. 28, n. 8, 1975, p. 699-715.

QUINE, W.V.O. Pursuit of Truth. Cambridge, MA.: Harvard University Press, 1990.

RAZ, J. Authority, Law, and Morality. The Monist, v. 68, n. 3, 1985, p. 295-324.

RAZ, J. The Morality of Freedom. Oxford: Oxford University Press, 1986.

RAZ, J. Notes on Value and Objectivity. In: LEITER, B. (ed.). Objectivity in Law and Morals. Cambridge: Cambridge University Press, 2001.

SCANLON, T.M. Being Realistic about Reasons. Oxford: Oxford University Press, 2014. 
SHAPIRO, S. Legality. Cambridge, MA.: Harvard University Press, 2011. SUNSTEIN, C. The Law of Group Polarization. Journal of Political Philosophy, v. 10, n. 2, 2002, p. 175-195.

ZUBER, J.; CROTT, H.; WERNER, J. Choice Shift and Group Polarization: An Analysis of the Status of Arguments and Social Decision Schemes. Journal of Personality and Social Psychology, v. 62, 1992, p. 50-61. 